\title{
Should Posterior Vitrectomy be Made a Priority in Ophthalmic Facilities of Sub Sahara Africa?
}

\author{
Oluleye Tunji Sunday*
}

Retina and Vitreous Unit, Department of Ophthalmology, University College Hospital, PMB 5116, Ibadan, Nigeria

\begin{abstract}
Background: Posterior vitrectomy facilities are lacking in Sub Sahara Africa due to paucity of trained personnel in vitreo retinal subspecialty. More cases are seen needing vitrectomy, especially cases with vitreous opacities and complications of cataract surgery as more residents are being trained. The review will aim to determine whether vitrectomy facility should be a priority as part of ophthalmic facility in the region.

Method: A 3 year review was carried out. All cases of posterior vitrectomy performed at the retinal unit of the University College Hospital, Ibadan, Africa between 2008 and 20011 were retrieved. Indications, and visual outcome were documented. Proportions and percentages were used to analyse the data.

Results: Sixty six posterior vitrectomies were performed during the period. The most common indication for vitrectomy was vitreous hemorrhage $\mathrm{n}=30$ [45.5\%].Complication of cataract surgery such as dropped intraocular lens 7 [10.7\%], sclera fixated intra ocular lens 6 [9.2\%], and dropped nucleus 5 [7.5\%] were emerging indications. Other indications noted include complicated retinal detachments $4(6.1 \%)$, membranectomy for posterior capsule opacity from pediatric cataract surgery $3(4.5 \%)$ and congenital lens subluxation $2(3.0 \%)$. Improved visual outcome was noted after surgery. Forty nine [75\%] eyes were blind [visual acuity of $<3 / 60$ ] before vitrectomy. This proportion dropped to 24 [37\%] after vitrectomy with an additional $24 \%$ regaining navigational vision [visual acuity of $3 / 60$ to Counting fingers at $1 \mathrm{~meter}$ ]

Conclusion: Vitrectomy should be an integral part of eye care and its availability should be made a priority in ophthalmic facilities of Sub Sahara Africa, especially those involved in ophthalmology training.
\end{abstract}

Keywords: Cataract surgery complications, posterior vitrectomy, retinal, sub Sahara Africa, vitreous opacities.

\section{INTRODUCTION}

Posterior vitrectomy is not a commonly performed procedure in ophthalmic facilities of Sub Sahara Africa. This is due to paucity of trained vitreoretinal surgeons in the region. Management of posterior segment disorders, such as clearing of vitreous opacities and complicated retinal detachments are possible with vitrectomy. Furthermore, management of certain anterior segment disorders may be improved with the availability of vitrectomy. With the increase in ophthalmic postgraduate training, the number of cataract surgeries in Sub Sahara Africa has increased hence the number of vitreoretinal complications requiring vitrectomy. Our center, the University College Hospital got a donation of posterior vitectomy equipment from the International Council of Ophthalmology (ICO). Sponsored fellowship training in vitreoretinal surgery was also awarded. In the last 3 years we have performed sixty six posterior vitrectomy procedures. Most of the procedures were inevitable. The present study reviewed the indications for performing the procedure so as to determine whether having the facility should be a priority among ophthalmic institutions in Sub Sahara Africa.

*Address correspondence to this author at the Retina and Vitreous Unit, Department of Ophthalmology, University College Hospital, PMB 5116, Ibadan, Nigeria; Tel: +2348023265594; Fax: +234 (2) 241 1768;

E-mail: t_oluleye@yahoo.co.uk

\section{METHODOLOGY}

The University of Ibadan and the University College Hospital, Ibadan ethical review board gave approval for the study. The retinal register of patients that had vitrectomy was reviewed and 66 cases were done over a-3-year period (2009 to 2011). The indications for the procedure were documented in the data sheet. Other information extracted from the individual patient's case record were age, gender, pre operative visual acuity (VA) and post operative VA as at the last clinic visit. Proportions and percentages were used to analyze the data.

\section{RESULTS}

Sixty six patients (eyes) had vitrectomy during the period under review. Male to female ratio was 3:1. The most common indication for vitrectomy was vitreous hemorrhage30 [45.5\%]. Complication of cataract surgery such as dropped intraocular lens $7[10.7 \%]$, sclera fixated intra ocular lens 6 [9.2\%], and dropped nucleus $5[7.5 \%]$ are emerging indications. Other indications noted include complicated retinal detachments $4(6.1 \%)$, membranectomy for posterior capsule opacity from pediatric cataract surgery $3(4.5 \%)$ and congenital lens subluxation $2(3.0 \%)$ (Table 1).

Visual outcome after surgery was remarkable. Forty nine [75\%] were blind [visual acuity $<3 / 60$ ] before vitrectomy. This proportion dropped to 24 [37\%] after vitrectomy with 
Table 1. Indications for Posterior vitrectomy in Ibadan, Sub Sahara Africa

\begin{tabular}{|c|c|c|}
\hline 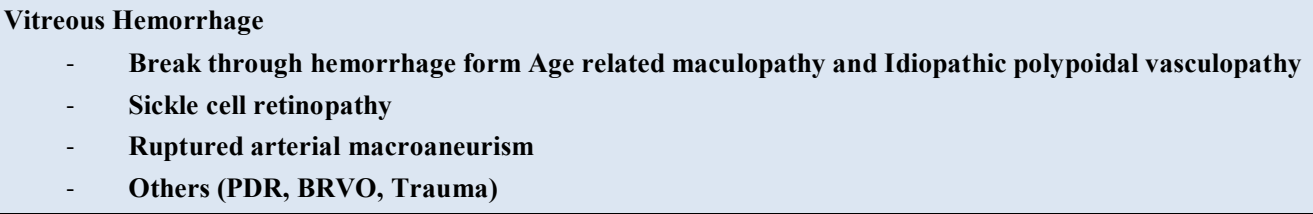 & $\begin{array}{l}30 \\
{[10]} \\
{[6]} \\
{[3]} \\
{[11]}\end{array}$ & 45.5 \\
\hline Scleral fixated IOL implantation & 6 & 9.2 \\
\hline Dropped Nucleus & 5 & 7.5 \\
\hline Complicated retinal detachment & 4 & 6.1 \\
\hline Membranectomy for PCO & 3 & 4.5 \\
\hline Total & 66 & 100.0 \\
\hline
\end{tabular}

*Vitreo macular traction, Endophthalmitis, chronic vitritis, AC IOL + vitreous in AC with cornea decompensation, silicone oil removal, suprachoroidal hemorrhage complicating cataract surgery.

PDR- proliferative diabetic retinopathy; BRVO- branch retinal vein occlusion; PCO- posterior capsule opacity; ACIOL- anterior chamber intraocular lens.

an additional 16 [24\%] regaining navigational vision [visual acuity 3/60- Counting fingers at 1 meter]. Only 8 patients [13\%] had no navigational vision compared to 32 [48\%] pre operatively (Table 2).

\section{DISCUSSION}

The commonest indication for vitrectomy in Ibadan, Africa was clearing of vitreous opacities, especially vitreous hemorrhage. Breakthrough vitreous hemorrhage from age related macular degeneration or Idiopathic polypoidal choroidal vasculopathy accounted for the majority of cases. Both these conditions are thought to be uncommon in the black population of Sub Sahara Africa [1-5]. Setting up of a vitreo retinal center with sponsored fellowship training in vitreoretinal surgery has improved diagnosis of these conditions in our center. They have recently been reported to be a significant cause of ophthalmic presentation in Nigeria [6]. Sickle cell retinopathy is another common cause of vitreous hemorrhage and an indication for vitrectomy in our center. Further, they have recently been reported to be a significant causes for ophthalmic presentation in Nigeria [6]. Sickle cell disease is a common condition in Sub Sahara Africa [7]. Sickle cell retinopathy is another common cause of vitreous hemorrhage and was an indication for vitrectomy in our center. Hemoglobin SC is a genetic blood disorder in which two different abnormal alleles, one for hemoglobin $\mathrm{S}$ and one for hemoglobin $\mathrm{C}$, are inherited. SC retinopathy is common in the western part of Nigeria, where our center is located $[8,9]$. Other causes of vitreous hemorrhage found included complications of hypertensive eye diseases such as branch retinal vein occlusion and ruptured retinal artery macroaneurysm. Systemic hypertension is on the rise in Nigeria and is now the most frequently diagnosed medical disease in the elderly, young executives and army recruits [10-13]. Proliferative diabetic retinopathy is also a significant cause of vitreous hemorrhage, with diabetic retinopathy an important cause of blindness and low vision in Nigeria [14,15]. Such that, it is likely there will be increasing demand for vitreoretinal surgery in the region.

Complications of cataract surgery are an emerging indication for vitrectomy. More cataract surgeries are being performed due to increased numbers of post-graduate doctors that are being trained. Lens nucleus drop and intraocular lens drop are important indications for vitrectomy while sclera fixation of intraocular lens for aphakia, pars plana membranectomy for dense posterior capsule opacity and

Table 2. Visual Outcome of Vitrectomy

\begin{tabular}{|c|c|c|c|c|}
\hline Vision category & Pre Operative Frequency & $\%$ & Post Operative Frequency & $\%$ \\
\hline Normal $($ VA $>/=6 / 18$ & 0 & 0 & 24 & 37 \\
\hline Low vision $\mathrm{VA}<6 / 18-3 / 60$ & 17 & 25 & 18 & 26 \\
\hline Blind $V A<\mathbf{3 / 6 0}$ & 49 & 75 & 24 & 37 \\
\hline $3 / 60-\mathrm{CF}[1 / 60]$ & {$[17]$} & {$[25]$} & {$[16]$} & {$[24]$} \\
\hline HM- LP & {$[32]$} & {$[48]$} & {$[7]$} & [11] \\
\hline NLP & {$[0]$} & {$[0]$} & {$[1]$} & {$[2]$} \\
\hline Total & 66 & 100 & 66 & 100 \\
\hline
\end{tabular}


suprachoroidal hemorrhage were emerging indications. It is expected that more of these complications will be seen as increasing numbers of residents are trained. In our study, one patient presented with corneal decompensation from anterior chamber intraocular lens implantation and vitreous touch. Early intervention with vitrectomy would have helped retained vision in the eye. Vitrectomy surgery was also performed for lens subluxations from congenital causes such as Marfan's syndrome and trauma. One case each of vitreomacular traction, chronic vitritis and silicone oil removal were seen.

Lens subluxations from congenital causes such as Marfan's syndrome were noted. Traumatic lens subluxation is also a significant indication for vitrectomy. Vitrectomy is best for these cases.

One case each of vitreo macular traction, chronic vitritis and silicone oil removal were seen. Vitrectomy improves the visual outcomes in these cases.

Visual outcome was remarkable in some patients especially those with vitreous hemorrhage and opacities. More than a third of the patient regained normal vision after vitrectomy from about two thirds that were blind before vitrectomy. Patients regaining navigational vision increased. Patients with no navigational vision reduced from about half [48\%] to $13 \%$. Cases such as complicated retinal detachments, suprachoroidal hemorrhage, vitreous touch and endophthalmitis still had poor vision despite vitrectomy. One case of post operative endophthalmitis presented with light perception that worsened to nil light perception post vitrectomy. This patient was also treated with intravitreal antibiotics. This eye eventually became phthysical.

\section{Conclusion}

Posterior vitrectomy surgery is an essential part of an ophthalmic unit. All cases discussed were performed through the pars plana. Ophthalmic training centers in Nigeria and Sub Sahara Africa should develop the vitreo retinal units in order to improve vision, particularly in patients with vitreous opacities and cataract complications.

\section{LIMITATIONS}

The study being a retrospective study, may be limited by accurate data retrieval from case records.

\section{CONFLICT OF INTEREST}

The author confirms that this article content has no conflict of interest.

\section{ACKNOWLEDGEMENTS}

The Eye clinic record staff of the University College Hospital, Ibadan, and the departmental staff are appreciated for their contribution.

\section{REFERENCES}

[1] Klein R, Klein BE, Knudtson MD, et al. Prevalence of age-related macular degeneration in 4 racial/ethnic groups in the multi-ethnic study of atherosclerosis. Ophthalmology 2006; 113: 373-80.

[2] Klein R, Rowland ML, Harris MI. Racial/ethnic differences in agerelated maculopathy. Third National Health and Nutrition Examination Survey. Ophthalmology 1995; 102: 371-81.

[3] Shih-Jen C, Ching-Yu C, Kai-Ling P, et al. Prevalence and Associated Risk Factors of Age-Related Macular Degeneration in an Elderly Chinese Population in Taiwan: the Shihpai Eye Study. Invest Ophthalmol Vis Sci 2008; 149(7): 3126-33.

[4] Friedman DS, Katz J, Bressler NM, et al. Racial differences in the prevalence of age-related macular degeneration: the Baltimore Eye Survey. Ophthalmology 1999; 106: 1049-55.

[5] Bressler SB, Munoz B, Solomon SD, et al. Racial differences in the prevalence of agerelated macular degeneration: the Salisbury Eye Evaluation (SEE) Project. Arch Ophthalmol 2008; 126: 241-5.

[6] Oluleye TS. Is Age related macular degeneration a problem in Ibadan, Sub Sahara Africa? Clin Ophthalmol 2012; 6: 561-4.

[7] Akinyanju OO. A profile of sickle cell disease in Nigeria. Ann N Y Acad Sci 1989; 565: 126-36.

[8] Majekodunmi SA, Akinyanju OO. Ocular findings in homozygous sickle cell disease in Nigeria. Can J Ophthalmol 1978; 13(3): 1602 .

[9] Abiose A, Lesi FE. Ocular findings in children with homozygous sickle cell anemia in Nigeria. J Pediatr Ophthalmol Strabismus 1978; 15(2): 92-5.

[10] Ogah OS. Hypertension in Sub Sahara African populations: the burden of hypertension in Nigeria. Ethn Dis 2006; 16: 765.

[11] Bella AF, Baiyewu O, Bamigboye A, et al. The pattern of medical illness in a community of elderly Nigerians. Cent Afr J Med 1993; 39(6): 112-6

[12] Okojie OH, Isah EC, Okoro E. Assessment of health of senior executives in a developing country. Public Health 2000; 114(4): 273-5.

[13] Awoyemi AO, Osagbemi GK, Ogunleye VA. Medical examination findings among army recruits in Ilorin. West Afr J Med 2001; 20(3): 256-8.

[14] Nwosu SN. Diabetic Retinopathy in Nnewi, Nigeria. Nig J Ophthamol 2000; 8(1): 7-10.

[15] Nwosu SN. Low vision in Nigerians with diabetes mellitus. Doc Ophthalmol 2000; 101(1): 51-7.

(C) Oluleye Tunji Sunday; Licensee Bentham Open

This is an open access article licensed under the terms of the Creative Commons Attribution Non-Commercial License (http://creativecommons.org/licenses/by$\mathrm{nc} / 3.0 /$ ) which permits unrestricted, non-commercial use, distribution and reproduction in any medium, provided the work is properly cited. 